\title{
Valts Liepiṇš
}

\section{Pacientam pielāgota digitāla aortas modela izveides automatizācỉjas iespējas \\ Opportunities for automatic creation of personalized digital aorta model}

E-pasts: valts197@gmail.com

Līdzautori: Jānis Virbulis un Vadims Geža

\begin{abstract}
Thoracic aorta aneurysm is a pathological enlargement of aorta, which develops asymptomatically and untreated can cause lethal consequences.

At the moment, the diameter of the aorta is used for the diagnosis of this disease, which is measured from computed tomography images. However, this criterion leaves around $1 / 3$ of cases undiagnosed [Neri et al., 2005]. The aim of this study was to create a model for calculating blood flow in the thoracic aorta, based on which a diagnostic method using the physical flow parameters could be created. Computed tomography images of real patients were used for creation of digital models of the aorta. These images were processed by a medical image analysis software "3DSlicer". To commence numerical flow calculations, the inflow and outflow regions of the acquired surface mesh were found, and a threedimensional mesh of finite elements was generated. OpenFOAM, an open source computational fluid dynamics toolbox was used for numerical flow calculations. To customize the method for each individual case, it is important to achieve an automatic recognition of the structure of the aorta. This was achieved by generating a skeleton of the surface model, which describes the topology of the aorta. Blood flow simulations in stationary and dynamic conditions were conducted, using the generated three-dimensional mesh, simultaneously optimizing the most fitting boundary conditions to the region that is being studied.

The suitability of the generated mesh for fluid dynamics simulations was tested in this study. The next step is the simulation of a physiological blood flow that takes
\end{abstract}


into account the individual blood flow parameters of the patient, as well as the elastic effects of the overall arterial tree on the flow in the aorta.

Keywords: blood flow simulation, aortic aneurysm, OpenFOAM, patient-specific mesh generation

\section{levads}

Aorta ir lielākā artērija cilvēka k̦ermenī, kura ir savienota ar sirdi un no kuras izriet viss arteriālais asinsvadu koks. Tā sastāv no divām daḷām - torakālās un vēdera aortas. Torakālā aorta sastāv no trīs posmiem: augšupejošās daḷas, loka un lejupejošās daḷas. Torakālās aortas loka liekums ir lielāks par $180^{\circ}$, un no tā atdalās trīs lielas artērijas, kas apasino galvu un abas rokas.

Aortas aneirisma ir slimība, kas novājinātas aortas muskulatūras un aortā valdošā augstā asins spiediena iespaidā sāk deformēt aortas sieniṇas. Neārstēta aortas aneirisma var novest līdz aortas plīsumam, kurš parasti ir letāls slimības iznākums [Braunwald et al. 2001]. Šī galvenokārt ir vecuma ierosināta slimība, un Latvijā 40\% no aortas aneirisma slimniekiem mirst pēkšṇā nāvē. Šobrīd šī slimība tiek diagnosticēta, novērtējot aortas diametru [2014 ESC Guidelines on the diagnosis and treatment of aortic diseases 2014]. Tomēr ar šo metodi nav iespējams diagnosticēt 1/3 no slimības izpausmes gadījumiem [Neri et al. 2005]. Tā kā cilvēku kermenu izmēri un to proporcijas ir dažādas, šĩ diagnosticēšanas metode ir nepietiekama. Tā vietā slimības kritērijus varētu balstīt uz pacienta asins plūsmas īpašībām, kas arī ir viens no aortas deformācijas tiešajiem cēloṇiem. Viens no veidiem, kā šādu diagnostikas metodi var realizēt, ir izveidot pacienta aortas fizikāli akurātu modeli, uz kura būtu iespējams simulēt pacientam pielāgotu asins plūsmu. Ir svarīgi izstrādāt vienotu šāda modeḷa uzstādīšanas metodoloǵiju, lai būtu iespējams veikt tālākus pētījumus un salīdzināt dažādu pacientu aortu simulāciju rezultātus. Viens no šīs metodoloǵijas posmiem ir pacienta aortas atveidošana virtuālā vidē, kuras apskats un metožu salīdzinājums ir galvenais šī pētījuma mērḳis. Pētījumā izvirzītie uzdevumi bija izveidot automatizētu metodi uz pacienta aortas balstīta skaitliskā režǵa ǵenerēšanai, to pārbaudīt ar tuvinātu asins plūsmas skaitlisko aprēḳinu un dažādu aortas simulācijas robežnosacījumu izpēti. 
Asins ir neṇūtona veida šḳidrums ar viskoelastiskām īpašībām. Tas nozīmē, ka tās plūsmas attīstība ir grūtāk paredzama nekā ūdenim līdzīgām vielām. Papildu sarežǵîtību asins plūsmas attīstības simulēšanai rada artēriju elastīgā daba, kas asins spiediena iespaidā nepārtraukti izplešas un saraujas. Tādēl fizioloǵiski akurāta asins plūsmas skaitliskā modelēšana ir ārpus šĩ pētījuma iespējām. Tā vietā asins plūsma tika simulēta ar nūtona veida šḳidruma tuvinājumu un artēriju elastība tika ignorēta. Šie skaitliskie aprēḳini tika veikti, lai objektīvi novērtētu pētījumā izstrādātā režǵa kvalitāti un lietojamību skaitlisko aprēḳinu veikšanai.

Aortas modeḷa izstrāde tiek sākta ar pacienta aortas izmēru un formas iegūšanu. Ërts un neinvazīvs risinājums ir datortomogrāfija, kas l̦auj iegūt aortas telpisko attēlojumu ar akurātiem izmēriem un proporcijām. N̦emot vērā, ka aorta nepārtraukti pulsē un maina savus izmērus asins cirkulācijas laikā, ir nepieciešams sasinhronizēt iekārtu, kas veic datortomogrāfijas uzṇēmumu, ar asinsrites cikla pulsu. Šādi ir iespējams iegūt asu jeb fokusētu visa krūškurvja telpisku attēlu. Datortomogrāfijas uzṇēmumu apstrādei šajā pētījumā tika izvēlēta "Kitware" programatūra "3DSlicer” [Slicer.org. 2019]. Šĩ ir bezmaksas atvērtā pirmkoda programatūra, kuru izstrādā atzīta kompānija, kas nodrošina ilgtermiṇa programatūras atbalstu, pieejamību un padara metodoloǵiju atkārtojamu citām pētniecības grupām. Ar šīs programmas palīdzību ir iespējams atlasīt telpisku apgabalu, kas atbilst viena veida audiem. Šo apgabalu var saglabāt kā trīsdimensionālu virsmas modeli, kuru ir iespējams apstrādāt ar dažādiem modelēšanas rīkiem.

Šādi iegūts aortas virsmas modelis vēl nav derīgs skaitlisko aprēḳinu veikšanai. legūtā virsma vietām var būt nepietiekami gluda vai aortas modeḷa gali noapalıti un ar neizteiksmīgām robežām (skat. 1. attēlu). Šie defekti rodas no datortomogrāfijas izšḳirtspējas ierobežojumiem, kur audu reǵionu robežas ir pārāk izplūdušas, lai akurāti rekonstruētu trīsdimensionālu virsmas modeli. Virsmas gludināšanai eksistē dažādi efektīvi risinājumi, tomēr lielākas problēmas sagādā aortas galu kvalitātes uzlabošana. Aortas modeḷa galu kvalitāte ir būtiska, jo, lai veiktu skaitliskus aprēḳinus, ir nepieciešams norādīt asins plūsmas sākuma nosacījumus, kurus definē uz fizikālā apgabala ieplūdes un izplūdes virsmām. Sākuma nosacijjumi ir jānorāda uz plakanas virsmas, kas ir apskatāmās caurules, šajā 


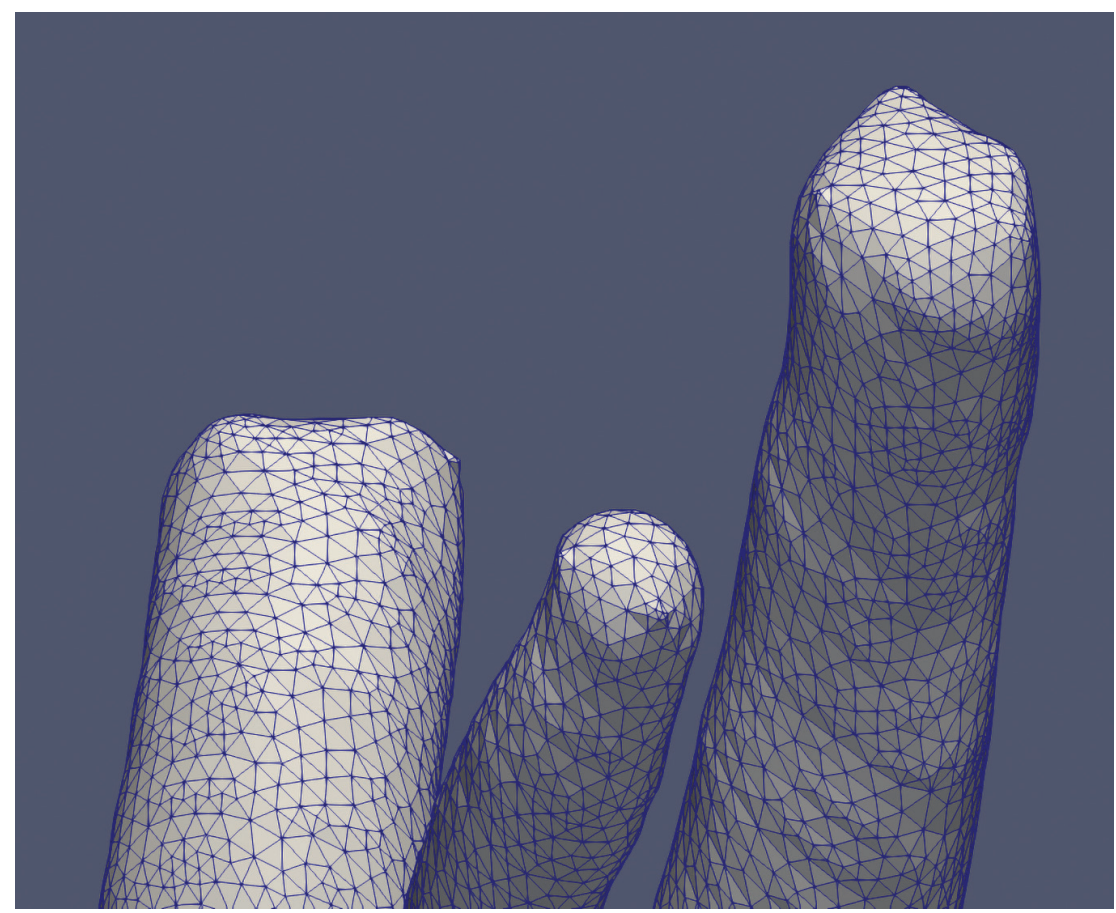

1. attēls. Trīs lielākie aortas atzari, caur kuriem asinis izplūst no aortas. Skaitlisko aprēḳinu veikšanai visām izplūdēm un ieplūdēm ir nepieciešams norādīt atvērto virsmu, līdz ar to ir jānošḳeḷ aortu galu noapalıjumi

gadījumā aortas, šḳērsgriezums. Šo šḳērsgriezumu ir iespējams norādīt patvalịgi, bet, tā kā pētījuma mērkis ir izstrādāt vienotu aortas apstrādes metodoloǵiju, šis process ir jāautomatizē.

Pirmā pētījumā izstrādātā metode balstās uz atsevišḳu virsmas elementu savstarpējo analīzi un ḷauj atrast asus pārliekuma punktus uz virsmas. Dažos gadījumos šādi var veiksmīgi atrast aortas galus, tomēr šī metode nebija uzticams risinājums. Otrā pētījumā izstrādātā metode balstās uz virsmas topoloǵijas analīzi un pievērš uzmanību aortas formas struktūrai. Viegli apstrādājamu virsmas modeḷa struktūru ir iespējams iegūt ar CGAL rīkkopas virsmas skeletizācijas rīku, kurš no virsmas modela iegūst viendimensionālu ǵeometrisku objektu (skat. 2. attēlu).

Apstrādātais aortas virsmas modelis tālāk var tikt izmantots, lai ǵenerētu trīsdimensionālu režǵi skaitlisko aprēḳinu veikšanai ar galīgo 


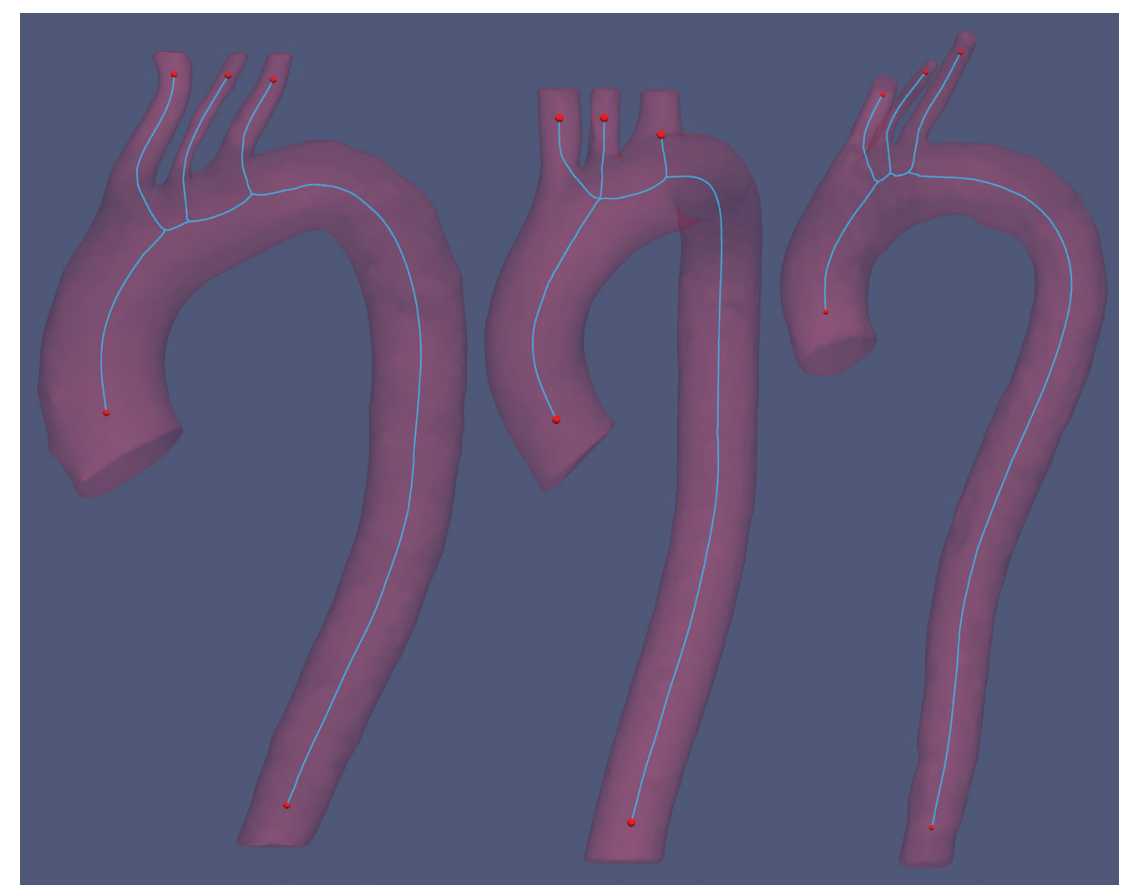

2. attēls. Trīs dažādu pacientu aortu modeḷi. Ar zilu līniju ir attēloti automātiski uzǵenerētie virsmas modeḷa skeleti. Ar sarkaniem punktiem ir atzīmēti automātiski atrastie modeḷa galapunkti, kas ir nepieciešami, lai nogrieztu noapalıtos aortu galus

elementu metodi (Finite Element Method). Galīgo elementu režği ir iespējams uzǵenerēt, izmantojot vienu no divām metodēm: kombinējot matemātiski vienkārši uzdodamu formu režǵus, līdz tiek iegūts vēlamās formas režǵis, vai arī uzǵenerējot visaptverošu maza izmēra elementu bāzes režǵi, iezīmējot tajā vēlamās formas reǵionu, un tad, paturot tikai šim reǵionam piederošos elementus, uzlabo robeželementu atbilstību vēlamajai formai. Šajā pētījumā tika izvēlēta otrā, lejupejošā stila, režǵa ǵenerēšanas metode. Lai gan šai metodei ir augsta uzstādīšanas sarežǵīīiba ar lielu pielāgojamo parametru skaitu, šī metode lauj izveidot strukturētu režǵi no brīvformas virsmas modeḷa. Šāda režǵa ǵenerēšanai tika izvēlēts "OpenFOAM" "snappyHexMesh" rīks.

Lai novērtētu iegūtā režǵa lietojamību, uz tā tika veikti vairāki hidrodinamikas aprēḳini. Veiktie aprēḳini neatbilst fizioloǵiskajai asins plūsmai, 
kuras akurātai simulēšanai būtu jāṇem vērā aortas sienu kustības dinamika un visa arteriālā asinsvadu koka elastības ietekme uz šo plūsmu.

\section{Metodes}

Pacientam izveido torsa datortomogrāfijas uzṇēmumu, kurš tiek veikts piecu minūšu laikā, un katru mērījumu veic sistoles sākuma momentā. Sistoles sākuma momentu nosaka ar kardiogrammas palīdzību, kas ir savienota ar datortomogrāfijas konsoli. legūto datortomogrāfijas uzṇēmumu apstrādā ar "Kitware" "3DSlicer" programmatūru, iezīmējot trīsdimensionālu aortas audu reǵionu, kuram tiks izstrādāts skaitliskais modelis. lezīmēto reǵionu ekstrapolē ar "3DSlicer" funkciju "Grow from seeds" un eksportē kā trīsdimensionālu virsmas modeli STL formātā.

Pirmā izstrādātā aortas virsmas modeḷa galu atrašanas metode balstās uz atsevišḳu virsmas elementu analīzi. Izmantojot "OpenFOAM" "surfaceFeatures" rīku, atrod visus punktus starp elementiem, kuru savstarpēji veidotais leṇkis ir šaurāks par $172^{\circ}$. Šāds leṇḳis tika izvēlēts, jo tas ir pietiekami šaurs, lai netiktu n,emts vērā aortas virsmas negludums un lai tas atbilstu aortas galu noapalıjumam. legūto punktu filtrēšanai un grupēšanai izmanto "DBScan" algoritmu ar parametriem minimālajam blakusesošo punktu skaitam, kas no apskatāmā punkta atrodas tuvāk par attālumu. Katrai izfiltrētajai punktu grupai atrod plakni, kurā grupas punkti ir izkārtoti, izmantojot mazāko kvadrātu metodes ǵeometrisko interpretāciju ar literatūrā piedāvāto algoritmu [Eberly 1999]. Plaknes izmēri atbilst aortas šḳērsgriezuma vietas diametram ar mazu papildus pievienotu robežu. legūtās plaknes saglabā atsevišḳi kā trīsdimensionālas virsmas modelus STL formātā.

Otrā izstrādātā aortas virsmas modeḷa galu atrašanas metode balstās uz aortas virsmas modeḷa topoloǵisku analīzi. Izmantojot rīkkopas CGAL "Triangulated Surface Mesh Skeletonization" algoritmu, tiek iegūts virsmas struktūras skelets, kā viendimensionāls telpisks objekts [CGAL Editorial Board 2019]. Apskatot katru no struktūras skeletu veidojošajiem punktiem, atrod tādus punktus, kuri ir savienoti tikai ar vienu blakusesošu punktu. Šos punktus sauc par gala punktiem. Apskata taisni, kas savieno gala punktu ar tā blakusesošo punktu un to pagarina gala punkta virzienā, 
līdz tā šḳērso aortas modeḷa virsmu. Krustpunkta atrašanai izmanto CGAL "AABB Tree" algoritmu. Izveido šḳērsgriezuma plakni uz pagarinātās taisnes vietā, kur aortas diametra izmaiṇa ir nemainīga. legūtās plaknes saglabā atsevišḳi, kā trīsdimensionālas virsmas modeḷus STL formātā.

legūto plakni kopā ar aortas virsmas modeli uzdod "OpenFOAM" "snappyBlockMesh" rīka konfigurācijas failā un ǵenerē trīsdimensionālu galīgo elementu režǵi.

legūtā aortas režǵa modelis tiek pārbaudīts, uz tā veicot asins plūsmas aprēḳinus, izmantojot N̦ūtona veida šḳidruma tuvinājumu. Šḳidruma plūsmas attīstība tika risināta ar Navjē-Stoksa parciāldiferenciālvienādojumiem, izmantojot galīgo elementu metodi. Šis aprēḳins tika veikts, stacionāram gadījumam izmantojot "OpenFOAM" "simpleFoam” risinātāju. Kā ieplūdes robežnosacījumu izmantoja plūsmas daudzumu, bet izplūdes robežnosacījumi tika fiksēti uz lielu spiedienu.

\section{Rezultāti un diskusija}

Pētījumā tika izstrādātas divas dažādas metodes aortas virsmas modeḷa ieplūdes un izplūdes robežu meklēšanai. Sākotnēji izstrādātā metode tika balstīta uz atsevišḳu virsmas modeḷa elementu analīzi. Šāda metode nespēja apmierinoši atpazīt atvērtos galus dažādu formu, izmēru un kvalitātes aortu modeḷiem. Secinot, ka izvēlētā metode ir neadekvāta aortu modeḷu apstrādei, tika apsvērti alternatīvi veidi, kā analizēt aortas virsmas modeli. Pievēršot uzmanību aortas virsmas modeḷa vispārējai formai, tika izvirzīta ideja vienkāršot trīsdimensionālo aortas modeli, saglabājot tikai tās strukturālo informāciju. Apskatot virsmas modeḷa reducēšanas risinājumus, tika atrasta virsmas skeletizēšanas metode. Ar virsmas skeletu veiksmīgi izdevās automātiski atrast dažādu aortas modeḷu robežas.

No apstrādātā aortas virsmas modeḷa izdevās izveidot trīsdimensionālu skaitlisko režǵi (skat. 3. attēlu), uz kura bija iespējams veikt šḳidrumu dinamikas skaitliskos aprēḳinus. Lai gan no aprēḳiniem bija iespējams iegūt fiziski ticamus rezultātus, režǵa kvalitāte asins plūsmas skaitlisko aprēḳinu veikšanai būtu nepietiekama. Kvalitāti būtu iespējams uzlabot, izveidojot režǵa robežslāṇus, kā arī panākot, lai bāzes režǵa elementi būtu orientēti līdz ar aortas lejteces virzienu. 


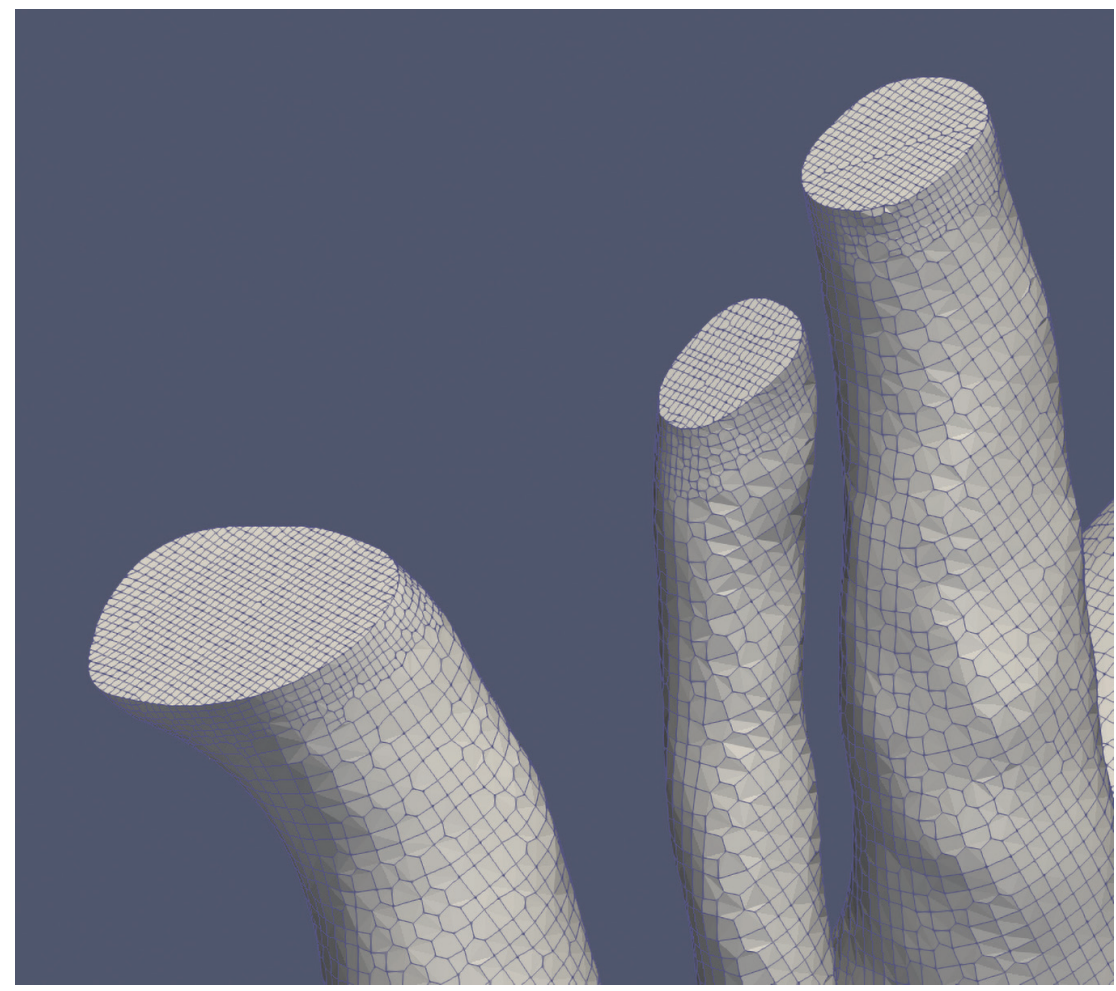

3. attēls. Trīs lielākie aortas atzari ar automātiski nošḳeltiem galiem. Ar zilām līnijām ir attēlotas uz virsmas redzamās trīsdimensionālā skaitliskā režǵa šūnu šḳautnes. Ar līdzīgām šūnām ir aizpildīts viss aortas modeḷa tilpums

Veiktajiem hidrodinamikas skaitliskajiem aprēḳiniem tika izvēlēti fizioloǵiskai asins plūsmai līdzīgi sākuma nosacījumi. Tika apskatīti dažādi modeḷi aortas asins plūsmas robežnosacījumiem. Pēc literatūras izpētes tika secināts, ka vislielāko ietekmi uz asins plūsmas fizioloǵisko akurātumu atstāj arteriālā asinsvadu koka elastības ietekme uz plūsmu aortā [Olufsen 1999]. Olufsenas pētījumā tika izstrādāta metode trīsdimensionāla aortas apgabala apvienošanai ar viendimensionālu arteriālā koka modeli, ko savā pētījumā izstrādājuši Vignons un Teilors [Vingon, Taylor 2004]. Lai gan arteriālā koka elastība parasti netiek n,emta vērā, Olufsenas pētījums veiksmīgi nodemonstrēja tā ietekmes būtību. Līdz ar to turpmākos 
pētījumos būtu jāvelta uzmanība arteriālā koka ietekmei uz asins plūsmu aortas modelī.

\section{Secinājumi}

Ir izdevies izstrādāt algoritmu un programmatūru pacienta aortas skaitliska modeḷa izveidei no datortomogrāfijas uzṇēmumiem.

Pacientam pielāgotā skaitliskā režǵa izveides automatizācijai visstabilākā metode ir aortas virsmas strukturālā skeleta analīze, ar kuras var atrast aortas robežu ǵeometriskos apgabalus.

\section{Izmantotā literatūra}

1. Braunwald, E., Libby, P. and Zipes, D. (2001). Heart Disease. Philadelphia, Pa: Saunders.

2. CGAL Editorial Board (2019). The Computational Geometry Algorithms Library. The CGAL Project. Pieejams: https://www.cgal.org/ (skatīts 15.11.2019.).

3. Eberly, D. (1999). Least Squares Fitting of Data by Linear or Quadratic Structures. Geometric tools. Pieejams: https://www.geometrictools.com/ Documentation/LeastSquaresFitting.pdf (skatīts 15.11.2019.).

4. Neri, E., Barabesi, L., Bukla, D., Vricella, L., Benvenuti, A., Tucci, E., Sassi, C., Massetti, M. (2005). Limited Role of Aortic Size in the Genesis of Acute Type A Aortic Dissection. European Journal of Cardio-Thoracic Surgery, 28(6), p. 857-863.

5. Olufsen, M. (1999). Structured Tree Outflow Condition for Blood Flow in Larger Systemic Arteries. American Journal of Physiology-Heart and Circulatory Physiology, 276(1), p. H257-H268.

6. Slicer.org. (2019). 3D Slicer. Kitware. Pieejams: https://www.slicer.org/ (skatīts 15.11.2019.).

7. Vignon, I. E., Taylor, C. A. (2004). Outflow Boundary Conditions for Onedimensional Finite Element Modeling of Blood Flow and Pressure Waves in Arteries. Wave Motion, 39(4), p. 361-374.

8. 2014 ESC Guidelines on the Diagnosis and Treatment of Aortic Diseases (2014). European Heart Journal, 35(41), p. 2873-2926. 